\title{
Consequences of variation in interval from insemination to ovulation on fertilization in pigs
}

\author{
B. Kemp and N. M. Soede \\ Agricultural University Wageningen, Wageningen Institute of Animal Sciences (WIAS), \\ Marijkeweg 40, 6709 PG Wageningen, The Netherlands
}

\begin{abstract}
This review describes effects of variation in the interval between insemination and ovulation on the fertilization process in the sow. Inseminations performed too early or too late relative to ovulation decrease litter size and especially farrowing rate. This effect can be explained to a large extent by the increase in the percentage of non-fertilized eggs, resulting in partial fertilization or no fertilization at all. No effects of variation in the interval from insemination to ovulation are found on the percentage of degenerate embryos. Only moderate effects are found on mean embryonic development and variation in embryonic development at day 5 after insemination. In general, insemination between 0 and $24 \mathrm{~h}$ before ovulation gives good fertilization results. Factors influencing the optimal interval from insemination to ovulation, such as number of sperm cells used for insemination, storage time of liquid semen and use of frozen semen, and sow factors such as parity and breed are discussed.
\end{abstract}

\section{Introduction}

Many reviews have been published about the distribution of spermatozoa within the genital tract after insemination and the fertilization process in the sow (for example Hancock, 1962; Baker and Polge, 1976; Hunter, 1982; Einarsson, 1985; Hunter, 1990; Flowers and Esbenshade, 1993). From these reviews it has become clear that eggs that enter the oviduct after ovulation have a short fertile lifespan and should therefore be fertilized quickly after ovulation by a population of capacitated sperm cells. Sperm cells seem to survive for extended periods after insemination when stored in the isthmus of the oviduct near the utero-tubal junction. The lifespan of eggs after ovulation and the lifespan of a sufficient number of sperm cells capable of fertilization within the oviduct therefore define the time during which inseminations can lead to successful fertilization relative to ovulation.

During recent years (especially with the development of ultrasound techniques to study the timing and process of ovulation) more quantitative data have become available on consequences of variation in the interval from insemination to ovulation for reproductive parameters. This review describes effects of variation in the interval from insemination to ovulation on fertilization in the sow. In addition, factors that influence the duration of the optimal interval from insemination to ovulation (in terms of fertilization) are discussed.

Knowledge of the range of interval from insemination to ovulation that leads to successful fertilization is important because it will set the accuracy with which insemination should be timed relative to ovulation. Together with the possibility for predicting ovulation during oestrus, this can lead to greater knowledge of the effects of insemination strategies on reproductive performance.

In spontaneously ovulating sows, the duration of ovulation ranges from 1 to $3 \mathrm{~h}$ (Soede $e t$ al., 1992); since this is a rather short period, in this review we refer to it as the moment of ovulation rather than the duration of ovulation. 


\section{Short Description of the Transport of Gametes to the Site of Fertilization}

Ovulation occurs about $30-35 \mathrm{~h}$ after the peak of the preovulatory LH surge, which is about $44 \mathrm{~h}$ after the onset of the preovulatory LH surge (Soede et al., 1994; Mburu et al., 1995). Eggs are transported to the site of fertilization at the ampullary-isthmic junction in $30-45 \mathrm{~min}$ or less (Hunter, 1974) and remain there for fertilization to occur.

During oestrus, sperm cells are deposited by AI or natural insemination at the utero-cervical junction and are transported to the utero-tubal junction due mainly to the contractile activity of the uterus (for review, see Einarsson, 1985). Although a large quantity of semen and a great number of spermatozoa are deposited into the uterus, only a relatively small number reach the oviducts (First $e t$ al., 1968; Hunter, 1982). The uterus is a hostile environment for sperm cells. The motility of sperm cells in the uterus decreases quickly after insemination and many sperm cells are removed from the uterus within a few hours after insemination by back flow and phagocytosis (Baker et al., 1968; Lovell and Getty, 1968; Pursel et al., 1978; Viring and Einarsson, 1980). Results from Viring and Einarsson (1981) show that within $2 \mathrm{~h}$ after insemination, approximately one-third of the inseminated sperm cells were found in back flow from the vagina. In our laboratory similar results were found (D. W. B. Steverink, unpublished) and although the amount of back flow showed a large variation between animals, this was not related to the fertilization results of the sows.

A sufficient number of sperm cells to effect fertilization have entered the oviduct within $15-30 \mathrm{~min}$ after insemination or mating. This population of sperm cells forms a sperm reservoir in the caudal 1-2 cm of the oviductal isthmus (Hunter, 1984). This reservoir has favourable storage conditions for sperm cells and regulates the release of capacitated, activated sperm cells to the site of fertilization.

The lifespan of eggs and the lifespan of a sufficient number of sperm cells in the sperm reservoir capable of fertilization define the time course during which insemination can be successful relative to ovulation.

\section{Limits of the Interval from Insemination to Ovulation}

Studies from the 1960s showed that sows inseminated early or late relative to oestrus showed a significant reduction in fertilization rate (Hancock and Hovell, 1962) and litter size and farrowing rate (Willemse and Boender, 1967). Since the time of ovulation relative to onset of oestrus varies considerably (for review, see Soede and Kemp 1997), these experiments do not lead to an accurate estimate of the effects of the interval from insemination to ovulation on reproduction. However, these studies did lead to the understanding that during the period of oestrus there were suboptimal and optimal times for insemination and that these were probably related to the moment of ovulation.

A summary of the results of experiments in which ovulation was controlled by hCG, or monitored by the progesterone rise or ultrasound, to study effects of variable intervals from insemination to ovulation on reproductive parameters given in Table 1.

Dziuk (1970) carried out a study in which double inseminations were performed at certain times relative to ovulation that was induced with hCG. He concluded that the optimal time for insemination was $12 \mathrm{~h}$ before ovulation and that a range of $6-18 \mathrm{~h}$ would probably have only moderately adverse effects on litter size. Hunter (1967a) studied effects of postovulatory inseminations on fertilization rate and concluded that eggs are optimally fertilized up to $8 \mathrm{~h}$ after ovulation and undergo normal development at least to the four- to eight-cell stage. Results of this early work should be interpreted with some caution since ovulation was induced with hCG and expected to occur at $40-42 \mathrm{~h}$ after induction. Experiments in which timing of ovulation after hCG injection was checked by slaughter, laparotomy or ultrasound show that ovulation time after hCG administration may vary between $35 \mathrm{~h}$ and $48 \mathrm{~h}$ (Hunter, 1967a, 1972; Pope et al., 1988; Brüssow et al., 1990; Soede and Kemp, 1993). Therefore, such data only allow rough estimates of the optimal interval from insemination to ovulation.

Helmond et al. (1986) assumed that ovulation occurred when progesterone increased by $1 \mathrm{ng}$ above basal values. However, Soede et al. (1994) showed that progesterone concentrations above 1 ng occurred 6-19 h (mean $13 \mathrm{~h}$ ) after ovulation as determined by ultrasound. After correcting for this, the estimate of optimal time of insemination of Helmond et al. (1986) would be $0-15$ h before 
Table 1. Estimates of the optimal time for insemination relative to ovulation in pigs

\begin{tabular}{|c|c|c|c|c|c|}
\hline \multicolumn{2}{|c|}{$\begin{array}{c}\text { Time range } \\
\text { (h before ovulation) }\end{array}$} & \multirow{2}{*}{$\begin{array}{l}\text { Al dose } \\
\left(\times 10^{9}\right)\end{array}$} & \multirow{2}{*}{$\begin{array}{l}\text { Evaluation time } \\
\text { (embryo age) }\end{array}$} & \multirow{2}{*}{$\begin{array}{l}\text { Ovulation } \\
\text { assessment }\end{array}$} & \multirow[b]{2}{*}{ Reference } \\
\hline Optimal & Studied & & & & \\
\hline \multicolumn{6}{|l|}{ Gilts } \\
\hline $12(6-18)$ & $6-30$ & $\begin{array}{c}10-15 \% \text { of an } \\
\text { ejaculate, } \\
\text { twice }\end{array}$ & Day $85-90$ & $40 \mathrm{~h}$ after $\mathrm{hCG}$ & Dziuk (1970) \\
\hline $6-8$ & $6-20$ & $\begin{array}{l}80-120 \mathrm{ml} \\
\text { semen }\end{array}$ & Day 3 & $41-42 \mathrm{~h}$ after $\mathrm{hCG}$ & Hunter (1967a) \\
\hline $13-28^{b}$ & $-16-48$ & AI & Day 3-10 & Progesterone rise ${ }^{c}$ & $\begin{array}{l}\text { Helmond et al. } \\
\quad(1986)\end{array}$ \\
\hline $0-12$ & $0-16$ & 2 & Day $2-5+28$ & $\begin{array}{l}\text { Ultrasound every } \\
4 \mathrm{~h}\end{array}$ & $\begin{array}{l}\text { Waberski et al. } \\
\text { (1994a) }\end{array}$ \\
\hline $0-24$ & $0->24$ & 2 & Day 2-4 & $\begin{array}{l}\text { Ultrasound every } \\
\because 12 \mathrm{~h}\end{array}$ & $\begin{array}{l}\text { Waberski et al. } \\
\text { (1994b) }\end{array}$ \\
\hline \multicolumn{6}{|l|}{ Sows } \\
\hline $0-24$ & $-16-48$ & 3 & Day 5 & $\begin{array}{l}\text { Ultrasound every } \\
\qquad 4 \mathrm{~h}\end{array}$ & $\begin{array}{l}\text { Soede et al. } \\
\text { (1995a) }\end{array}$ \\
\hline$-8-24$ & $-8-32$ & 3 & Day 5 & $\begin{array}{l}\text { Ultrasound every } \\
\qquad 4 \mathrm{~h}\end{array}$ & $\begin{array}{l}\text { Soede et al. } \\
\text { (1995b) }\end{array}$ \\
\hline$-4-28$ & $-9-41$ & 2 & $\begin{array}{l}\text { Day } 28+\text { full } \\
\text { term }\end{array}$ & $\begin{array}{l}\text { Ultrasound every } \\
6 \mathrm{~h}\end{array}$ & $\begin{array}{l}\text { Nissen et al. } \\
\quad(1997)\end{array}$ \\
\hline
\end{tabular}

33 gilts were inseminated twice and seven gilts were mated twice.

bhen data of Helmond et al. (1986) are corrected for the increase in progesterone after ovulation according to Soede et al. (1994), the optimal interval from insemination to ovulation ranges from $15 \mathrm{~h}$ to $0 \mathrm{~h}$ before ovulation.

'Ovulation time was assumed when plasma progesterone concentrations increased by $1 \mathrm{ng}$ above basal values.

ovulation. But again, owing to the variation in rise of progesterone after ovulation, these data should be interpreted with some caution.

Waberski et al. (1994a) used transcutaneous ultrasonography to assess ovulation and concluded that good fertilization rates were found in gilts inseminated between 0 and $12 \mathrm{~h}$ before ovulation. However, their estimate for the optimal interval from insemination to ovulation may not be very accurate as only a few animals were inseminated more than $12 \mathrm{~h}$ before ovulation $(n=5)$ and no animals were inseminated more than $16 \mathrm{~h}$ before ovulation.

Studies in which ultrasound was used to monitor the time of ovulation covering a wide range of intervals from insemination to ovulation (Waberski et al., 1994b; Soede et al., 1995a,b; Nissen et al., 1997 ) led to the conclusion that inseminations can be performed between 0 and $24 \mathrm{~h}$ before ovulation with no significant adverse effects on fertilization rate. This interval is significantly longer than previously reported values. Nissen et al. (1997) found optimal'results in terms of numbers of day 16 embryos and farrowing rate and litter size in sows inseminated between $28 \mathrm{~h}$ before ovulation and $4 \mathrm{~h}$ after ovulation (as detected by transrectal ultrasound).

Several factors may influence the range of optimal interval from insemination to ovulation as found by various workers and these will be discussed later in this review.

\section{Effects of Interval from Insemination to Ovulation on Partial Fertilization and Embryonic Development}

To study the effects of the interval from insemination to ovulation on subsequent fertilization, Soede et al. $(1995 \mathrm{a}, \mathrm{b})$ inseminated sows at various times relative to ovulation (as detected by transrectal 
ultrasound) and slaughtered the animals at about $120 \mathrm{~h}$ after ovulation to study fertilization rate and embryonic development. The morphology of the embryos was evaluated and the number of nuclei (to calculate the number of cell cycles) and of spermatozoa bound to the zona pellucida (accessory sperm count) was determined. An oocyte was classified as unfertilized if the nuclear count was zero or one. Embryos with degenerate morphology and a small number of nuclei were classified as degenerated; the remaining embryos were considered to be normal. Fertilization rate was defined as the percentage of normal embryos relative to all embryos and oocytes recovered. Sows were assigned on the basis of fertilization rate to classes varying from no fertilized eggs to total fertilization of all ovulated eggs. The number of degenerated embryos was about $4 \%$ irrespective of the interval between insemination and ovulation.

The percentage of sows within each class of fertilization rate is shown (Fig. 1) for different intervals from insemination to ovulation. The percentage of sows with partial or no fertilization increases when insemination takes place more than $24 \mathrm{~h}$ before ovulation or directly after ovulation. However, in these suboptimal periods a large variation between sows can be seen. Even when insemination occurs more than 40 h before ovulation, $15 \%$ of the sows showed $100 \%$ fertilization.

Mean embryo development in a litter and within litter variation in embryo development of normal embryos are shown in relation to interval from insemination to ovulation (Fig. 2). These data are from three experiments (Soede et al., 1995a, b; Steverink et al., 1997) and are corrected for experiment and age of embryos at slaugher (between $118 \mathrm{~h}$ and $130 \mathrm{~h}$ ). Although not significant, a longer interval from insemination to ovulation and inseminations after ovulation on average result in slightly lower embryonic development and increased variation in embryonic development. In the study of Soede et al. (1995a) in each insemination to ovulation class, successful fertilization (>90\% normal embryos) was significantly associated with better embryonic development. On average, development (corrected for embryo age) in terms of number of cell cycles was $5.7 \pm 0.7$ for the 'good fertility' sows and $5.1 \pm 0.8$ for the 'poor fertility' sows. This effect was completely independent of the interval from insemination to ovulation, which means that embryonic development of 'good fertility sows' inseminated at optimal or suboptimal intervals from insemination to ovulation was similar.

Therefore, these results show that variation in interval from insemination to ovulation induces partial fertilization or no fertilization; furthermore litters with partial fertilization also have slightly retarded embryo development and increased variation in embryonic development at day 5 of pregnancy. Whether the effect on embryo development has an impact on embryonic mortality remains to be investigated.

It should be mentioned that fertilization is often assumed to be an 'all or none' phenomenon; either all oocytes are fertilized or none are (see Hunter, 1994). The above mentioned studies clearly show that partial fertilization frequently occurs, even when timing of insemination relative to ovulation is optimal. This finding is of importance for research on embryo survival since embryo survival is normally defined as the number of embryos relative to the number of corpora lutea and assumes that fertilization rate is $100 \%$.

\section{Possible Causes of Reduced Fertilization at Long Intervals Between Insemination and Ovulation}

When insemination is performed early relative to ovulation the fertilization success depends on the lifespan of a sufficient number of sperm cells capable of fertilization in the sperm reservoir.

The functional sperm reservoir in pigs has been reviewed by Hunter (1990). In short, the sperm reservoir in pigs is established within 15-30 min after insemination in the caudal $1-2 \mathrm{~cm}$ of the oviduct. Sperm cells can be trapped in this reservoir for more than $36 \mathrm{~h}$ while motility of the sperm cells is depressed and the acrosomal membrane remains intact. By the time ovulation approaches, sperm cells are released and become hyperactive and are able to fertilize eggs. It was suggested that this synchronized release at the time of ovulation is co-ordinated at least in part by changing ovarian hormone concentrations after the LH surge influencing the oviduct through local countercurrent transfer from the ovarian vein and the oviductal branch of the ovarian artery. 


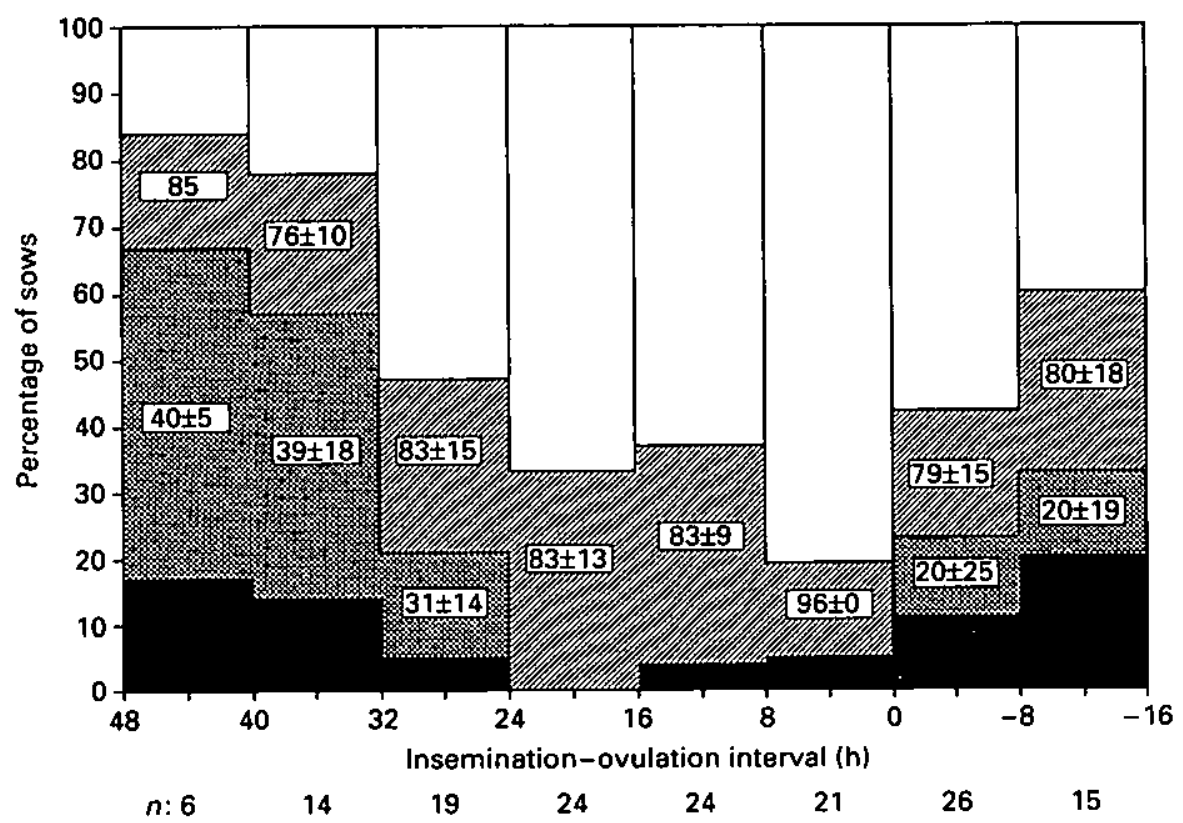

Fig. 1. Percentage of sows with $0 \%(\square), 0 \%-50 \%$ (国), 50\%-100\% (国) and $100 \%(\square)$ fertilization for each $8 \mathrm{~h}$ insemination to ovulation interval $(n=151)$. For sows with partial fertilization, mean fertilization rate (mean \pm SD) is given per time interval. (Reproduced from Soede et al., 1995a.)

Suarez et al. (1991) and Raychoudhury and Suarez (1991) showed that in vitro sperm cells bind to ciliated oviductal cells within minutes after incubation. Binding to the epithelium was improved when oestradiol was added to the medium. Binding of sperm cells to the epithelium was significantly reduced after $24 \mathrm{~h}$. Of those sperm cells that remained attached to the epithelium, $70 \%$ remained motile for more than $44 \mathrm{~h}$. Unbound sperm cells were not motile. It was also shown that the oviductal isthmus cells produced a thick mucus which traps sperm cells that are released from the epithelium.

Mburu et al. (1996) studied the distribution of spermatozoa in the pig oviduct in relation to spontaneous ovulation and showed that before ovulation most sperm cells were found in the lower isthmus and these sperm cells seemed partly trapped in thick mucus and in the folded endosalpinx. During and after ovulation the endosalpinx folds were much less pronounced, mucus was less viscous and the number of sperm cells in the lower oviduct was reduced. However, the number of sperm cells in the upper part of the oviduct was increased around and after ovulation.

Collectively these results seem to suggest that sperm cells enter the oviduct within $15 \mathrm{~min}$ after insemination and form a sperm reservoir at the caudal isthmus, because sperm cells attach to the epithelium and are trapped in a mucus plug and the intense folding of the isthmus. Sperm cells attached to the epithelium can survive for more than $44 \mathrm{~h}$. Around ovulation this reservoir is lost and sperm cells can be released to the oviduct.

It is not known why fertility is lower when inseminations are performed more than $24 \mathrm{~h}$ before ovulation if sperm cells are able to survive in the isthmus for more than $44 \mathrm{~h}$. A possible explanation is that the number of capacitated sperm cells capable of fertilization decreases over time and that this is the limiting factor for fertilization success. An indication that the number of capacitated sperm cells capable of attachment to the zona pellucida is lower with a longer interval from insemination to ovulation is the rapid decrease in number of accessory sperm cells in the embryos fertilized at longer intervals between insemination and ovulation as found by various authors (see Fig. 3).

Smith and Yanagimachi $(1990,1991)$ showed that in hamsters only uncapacitated sperm cells are capable of attachment to the isthmic epithelium. These sperm cells sometimes detach from the 


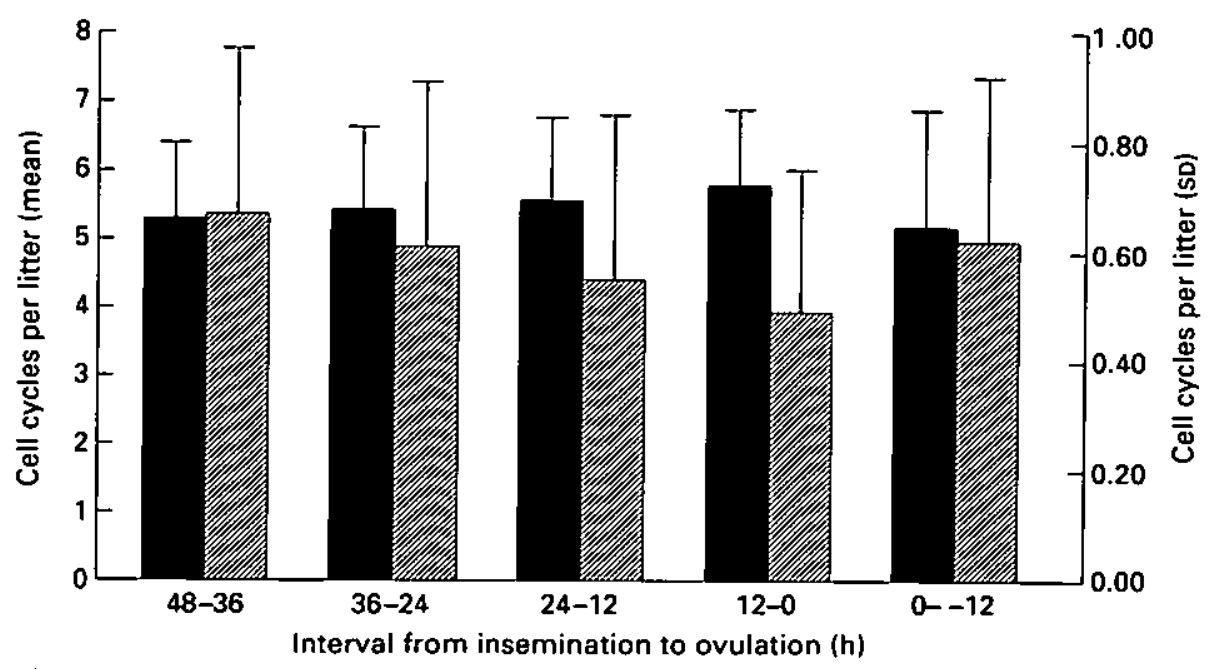

Fig. 2. Mean number of cell cycles ( $\square$ ) and standard deviation in cell cycles (四) within sows of day 5 embryos (corrected for age) at various $12 \mathrm{~h}$ intervals from insemination to ovulation. (Based on data from Soede et al., 1995a,b; and Steverink et al., 1997.)

epithelium for a short period and then re-attach (similar observations in mouse: Demott and Suarez, 1992). However, when sperm cells become capacitated they lose their affinity for oviductal mucosa. Further observations showed that most sperm cells that were not attached to the oviduct but detached before ovulation are dead and do not play a role in the fertilization process. Such observations seem to suggest that uncapacitated sperm cells are stored in the oviduct and that part of the population gradually becomes capacitated and enters the lumen of the oviduct. Populations of these capacitated sperm cells that are released long before ovulation will not survive and therefore the population of remaining sperm cells gradually decreases. Research on the mechanism that regulates the release of capacitated sperm cells from the epithelium of the oviductal reservoir before ovulation might improve our understanding of the causes of reduced fertilization at longer intervals between insemination and ovulation.

\section{Possible Causes of Reduced Fertilization due to Insemination after Ovulation}

When insemination takes place after ovulation, fertilization is often poor (as shown in Table 1 and Fig. 1). It is assumed that the decrease in fertilization rate is caused by the limited lifespan of the oocytes in combination with the time needed for sperm cells to capacitate and reach the site of fertilization (Hunter, 1994). Recent studies of oocytes and embryos from postovulatory insemination showed that fertilized oocytes contain large numbers of accessory sperm cells (see Fig. 3 ). This corresponds to the finding of Hunter (1984) that, after insemination, the regulation of the number of sperm cells passing from the uterus to the site of fertilization is less effective, and therefore increases the chance that oocytes are confronted by two or more spermatozoa simultaneously, increasing the rate of polyspermic fertilization. In pig husbandry, many sows are inseminated two or more times, with an interval between two subsequent inseminations of 12-24 h. A greater number of inseminations increases the chance of postovulatory insemination and consequently may increase the chances of polyspermic fertilization. To study this, Soede et al. (1995b) conducted an experiment in which sows were inseminated before ovulation followed by an insemination within $0-5 \mathrm{~h}$ after ovulation. The second insemination resulted in a marked increase in the number of accessory sperm cells but did not result in a decrease in the number of well-developed embryos at $120 \mathrm{~h}$ after ovulation. In addition, no relationship was found between the number of accessory sperm cells and embryonic 


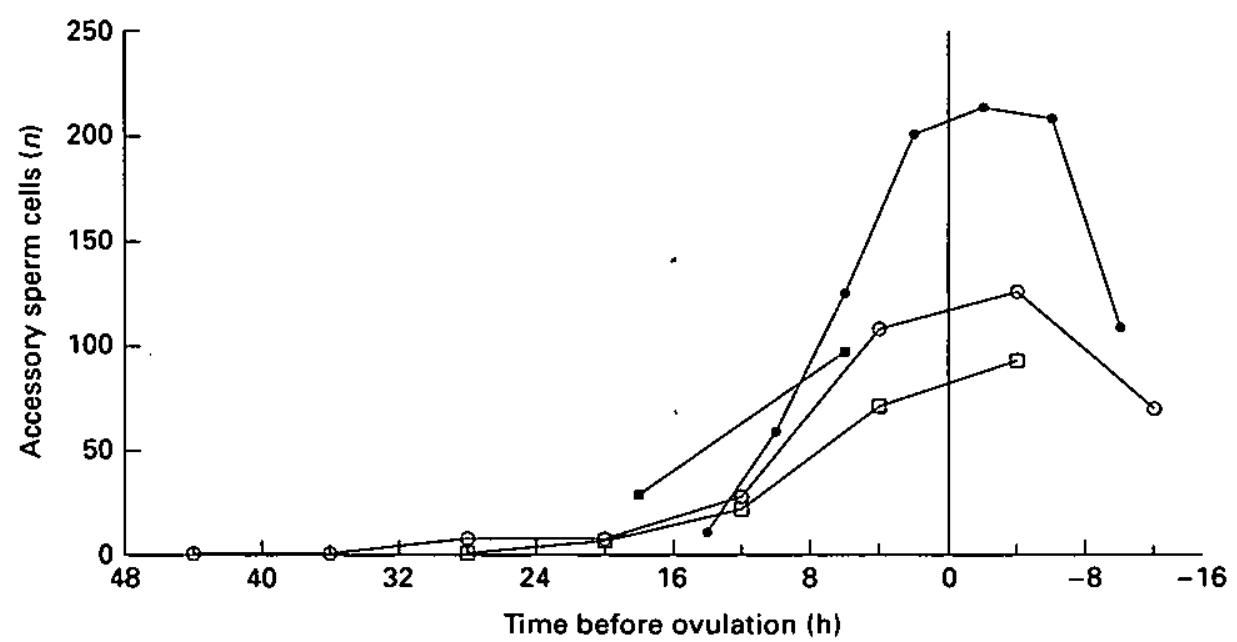

Fig. 3. Mean number of accessory sperm cells on day 2-5 embryos in relation to interval from insemination to ovulation. (Based on data from Waberski et al., 1994a, (O) b (ם); and Soede et al., $1995 \mathrm{a},(\mathrm{O}) \mathrm{b}(\square)$.)

development in sows inseminated a second time after insemination. It was concluded therefore that a second insemination after ovulation did not result in a reduction in normal fertilization. It might therefore be suggested that polyspermic fertilization. is not a cause of embryonic losses under normal artificial insemination conditions. Polyspermic fertilization is normally assessed in the first hours after fertilization by counting the number of sperm cells or pronuclei in the cytoplasm of the oocyte. Polyspermic embryos are said to degenerate early in development, but may seem normal for up to the four- to eight-cell cycle (Hunter, 1967b). In the experiment of Soede et al. (1995b) no assessment of polyspermic embryos was made; however, it can be assumed that (expanded) blastocysts at $120 \mathrm{~h}$ after ovulation are viable normal embryos not resulting from polyspermic fertilization.

Estimates of polyspermic fertilization have previously been made under unnatural conditions (progesterone injections, Day and Polge, 1968; hCG injection, Hunter, 1967a; oviductal inseminations, Hunter, 1973). Even polyspermic fertilization at the end of the fertile lifespan of oocytes (Hunter, 1967b) may not occur under natural conditions; reduced fertilization of sows inseminated after ovulation in the experiment of Soede $e$ al. (1995a) was due to lack of fertilization and not due to an increased incidence of degenerated embryos. Therefore, the time after ovulation in which successful inseminations can be applied seems to depend on the lifespan of the eggs or the capacitation rate of the sperm cells.

\section{Factors Influencing the Optimal Interval from Insemination to Ovulation in Sows}

\section{Parity and breed effects}

From the above mentioned studies it has become clear that success of fertilization depends on the interval from insemination to ovulation. However, it is also clear that there are large differences between individual sows. Although the general trend suggests that, if fresh semen is used at an adequate dose, the optimal interval from insemination to ovulation is between $0 \mathrm{~h}$ and $24 \mathrm{~h}$ before ovulation, it is clear that some sows have good fertilization results outside these limits and that some sows have poor fertilization results inside this time period.

To our knowledge there are no experiments that have studied the effect of parity on the optimal interval from insemination to ovulation. From the experiments listed in Table 1, it could be concluded that experiments performed in gilts result in a shorter optimal interval from insemination to 
ovulation. However, owing to the limited numbers of gilts used in these experiments and the various techniques used to detect ovulation, these results should be interpreted with caution. Furthermore, Waberski et al. (1994b) showed that fertilization in gilts was not affected by an interval from insemination to ovulation ranging from 0 to $24 \mathrm{~h}$ which is comparable with studies performed with older parity sows (as listed in Table 1).

In the experiments of Soede et al. $(1995 \mathrm{a}, \mathrm{b})$, three different genetic lines (one sow line and two boar lines) were used that were parent lines for commercial crossbreeds. Data from these experiments were used to study the possible effect of breed on fertilization rate at different intervals from insemination to ovulation. In Table 2, fertilization results are shown for boar and sow lines inseminated at different intervals from insemination to ovulation. The boar lines showed similar results and are therefore not separated. The data show that inseminations performed after ovulation resulted in marked differences between lines. The sow line showed good fertilization results, whereas boar lines showed a marked decline in fertilization. However, when insemination occurred before ovulation, the sows from the boar lines tended to have better fertilization results. These data suggest that oocyte survival, sperm transport, sperm survival in the oviduct or sperm capacitation may vary between breeds and consequently influence the optimal period for insemination relative to ovulation.

\section{Semen characteristics}

Semen characteristics might influence the optimal interval from insemination to ovulation. To our knowledge, no information is available on the effects of semen quality parameters assessed before insemination (like motility characteristics) on the optimal interval from insemination to ovulation. Information on the number of sperm cells inseminated, storage time of liquid semen and insemination with frozen semen is presented below.

Number of sperm cells inseminated. In the early years of AI, insemination dosages of $40 \times 10^{9}$ sperm cells were used (Rigby, 1966; First et al., 1968). In 1968, Baker et al. studied the effects of different volumes $(20,100$ or $200 \mathrm{ml})$ and different numbers of sperm cells $\left(1,5\right.$ or $10 \times 10^{9}$ sperm cells $)$ on the fertilization results after $\mathrm{AI}$ and concluded that best results were to be expected when using 5 or $10 \times 10^{9}$ sperm cells in a volume of $100 \mathrm{ml}$. During the following years new extenders and improved quality assessment of semen resulted in the use of dosages of $2.0-3.5 \times 10^{9}$ sperm cells (of which $70-90 \%$ were scored as motile) in $80-100 \mathrm{ml}$ in most countries (Colenbrander, 1991).

The experiments of Soede $\mathrm{et}$ al. $(1995 \mathrm{a}, \mathrm{b})$ were performed with a dose of $3 \times 10^{9}$ total sperm cells and the experiments of Waberski et al. (1994b) and Nissen (1995) were performed with a dose of $2 \times 10^{9}$ total sperm cells. These data collectively suggest that use of a dose of $2-3 \times 10^{9}$ sperm cells was compatible with an the optimal interval from insemination to ovulation of about 0-24 $\mathrm{h}$.

Steverink et al. (1997) studied whether this optimal interval could be longer when a higher sperm dosage $\left(6 \times 10^{9}\right.$ total sperm cells) was used or shorter when a lower sperm dosage was used $\left(1 \times 10^{9}\right.$ sperm cells). However, results showed that the optimal period for insemination of $0-24 \mathrm{~h}$ was hardly influenced by the dosages of spermatozoa applied in this study. These results indicate that the lifespan of the functional sperm reservoir is not very sensitive to variation in the number of sperm cells inseminated, at least not within the range of $1-6 \times 10^{9}$ total sperm cells.

Liquid semen storage before AI. Liquid semen can be stored after dilution in commercial extenders (for example BTS, Androhep or Kiev) for several days without apparent loss in fertilizing capacity. The general trend in the literature indicates that liquid semen can be stored up to about 3 days without adverse effects on litter size and pregnancy rate (Larsson et al., 1979; Aalbers et al., 1984; Waberski et al., 1990; Sather et al., 1991; Machaty et al., 1992; Baltes, 1993; Alexopoulos et al., 1996).

Waberski et al. (1994b) conducted an experiment to study effects of long-term storage of liquid semen in relation to fertilization rate at different intervals from insemination to ovulation. Semen 
Table 2. Percentage of normal embryos (mean \pm SEM) at day 5 after ovulation in sows of sow-lines ${ }^{a}$ and boar-lines ${ }^{b}$ with a variable interval between insemination and ovulation

\begin{tabular}{lccc}
\hline $\begin{array}{l}\text { Time of insemination } \\
\text { relative to ovulation }\end{array}$ & $\begin{array}{c}\text { Sow-lines } \\
(n=46)\end{array}$ & $\begin{array}{c}\text { Boar-lines } \\
(n=154)\end{array}$ & $P$ c \\
\hline $\begin{array}{l}\text { After ovulation } \\
\text { 0-16 h }\end{array}$ & $94 \pm 4$ & $62 \pm 6$ & 0.007 \\
$\begin{array}{l}\text { Before ovulation } \\
\text { 0-24 h }\end{array}$ & & & \\
24-48 h & $83 \pm 6$ & $92 \pm 2$ & 0.07 \\
\hline
\end{tabular}

-Sow-lines have been selected mostly for fertility parameters. Mothers of commercial crossbreed sows.

Boar-lines have been selected mostly for production parameters. Fathers of fattening pigs.

'Based on analyses with arcsine transformed percentages.

diluted in BTS and stored at $17^{\circ} \mathrm{C}$ for $0-48 \mathrm{~h}$ could be inseminated between 0 and $24 \mathrm{~h}$ before ovulation without apparent loss in fertilizing capacity (based on the percentage of good embryos at days $2-4)$. Semen stored for $48 \mathrm{~h}$ to $87 \mathrm{~h}$ resulted in a decrease in fertilization rate when inseminated more than $12 \mathrm{~h}$ before ovulation and semen stored for 87 to $118 \mathrm{~h}$ already resulted in a lower fertilization rate when inseminated between 0 and $12 \mathrm{~h}$ before ovulation. Postovulatory insemination (between 0 and $4 \mathrm{~h}$ after ovulation) with long-term stored liquid semen was carried out in a second trial. Fertilization rate seemed to decrease when semen was stored for more than $24 \mathrm{~h}$ in BTS and for more than $48 \mathrm{~h}$ in Androhep. Motility and percentage normal apical ridge assessed in vitro showed no decrease until after storage for $48 \mathrm{~h}$.

In the experiments of Soede et al. (1995 a, b), semen was diluted in BTS and retrospective analyses showed that storage times between $12 \mathrm{~h}$ and $38 \mathrm{~h}$ did not affect the optimal interval from insemination to ovulation. From these results it seems that storage time of liquid semen affects the optimal interval from insemination to ovulation and effects seem to depend on the type of extender used.

Frozen semen. Reduced fertility associated with frozen semen has been the main reason for its limited use in AI practice (Reed, 1985; Didion and Schoenbeck, 1996). In studies with hCG = treated sows, Larsson (1976) showed that insemination with frozen semen close to the expected time of ovulation resulted in the highest fertilization results. Waberski $e t$ al. (1994a) studied effects of interval from insemination to ovulation in spontaneously cyclic gilts on fertility using frozen semen. They showed that the percentage of normal day 2-5 embryos significantly decreased when insemination was performed more than $4 \mathrm{~h}$ before ovulation or directly after insemination. Fertilization rate in the group of sows inseminated between $0 \mathrm{~h}$ and $4 \mathrm{~h}$ before ovulation was $88.1 \%$, which was only slightly less than the fertilization expected when using fresh semen. However, a dose of $5 \times 10^{9}$ total sperm cells was used for insemination with frozen semen which is substantially higher than dosages used for fresh semen (Waberski et al., 1994a,b; Soede et al., 1995a,b). It was suggested (Pursel et al., 1978; Saacke, 1982) that cell damage after cryopreservation results in a higher elimination rate of sperm cells in the female tract, resulting in fewer spermatozoa at the site of fertilization. Comparing trials with liquid and frozen semen, Waberski et al. (1994a) found that insemination between 0 and $4 \mathrm{~h}$ before ovulation resulted in a tenfold reduction in the number of accessory spermatozoa when using frozen semen even though a higher dose of sperm cells $\left(5 \times 10^{9}\right.$ versus $\left.2 \times 10^{9}\right)$ was used in the frozen semen trial.

These results indicate that frozen semen seriously reduces the optimal interval from insemination to ovulation. In the Netherlands, fresh semen is used at a dosage of $2.5 \times 10^{6}$ sperm cells and frozen semen at a dosage of $10-15 \times 10^{6}$ sperm cells to obtain comparable pregnancy rates in cattle (van Wagtendonk, personal communication). Such a four- to six-fold increase in dosage is not an 
option for AI practice in pigs since only a limited number of dosages can be obtained from a boar. Perhaps timing of ovulation with hCG in combination with insemination just before ovulation is a better option.

\section{Conclusion}

Variation in the interval from insemination to ovulation affects fertilization rate in sows and results in partial fertilization or no fertilization at all. No effects are found on the percentage of degenerated embryos and only small effects are found on embryonic development.

In general, insemination between 0 and $24 \mathrm{~h}$ before ovulation gives good fertilization results; however, there are large differences between sows. Even in suboptimal periods some sows show $100 \%$ fertilization. This finding indicates that factors like storage conditions in the sperm reservoir, capacitation rate of semen in the sow and lifespan of the eggs and semen in the sow may vary considerably between individual sows. Part of this variation seems genetic but factors like insemination conditions (natural breeding versus AI) may also play a role. This role remains to be elucidated.

\section{References}

Aalbers JG, Johnson, LA, Rademaker JMH and Grooten HJG (1984) Use of boar spermatozoa for AI: fertility and morphology of semen diluted in BTS and used for insemination within $24 \mathrm{~h}$ or $\mathbf{2 5} \mathrm{h}$ after collection. In Proceedings of the 10 th International Congress on Animal Reproduction and Artificial insemination Vol. 2. Abstract 180

Alexopoulos C, Boscos C, Saratsis P, Saoulidis C and Kyriakis S (1996) The effect of storage time and number of spermatozoa per insemination dose on semen characteristics and fertilization capacity of boar semen diluted with BTS extender Animal Science 62 599-604

Baker RD and Polge C (1976) Fertilization in swine and cattle Canadian Journal of Animal Science 56 105-119

Baker RD, Dziuk PJ and Norton HW (1968) Effect of volume of semen and drugs on transport of sperm in artificial inseminated gilts joumnl of Animal Science 27 88-93

Baltes TJ (1993) Plasma membrane evaluation with fluorescent stains, and computer measured motility as indicators of in vilm aging of boar spermatozoa MSc Thesis, Tierarztlicher Hochschule Hannover

Brüssow KP, Ratky J, Kanizz W and Becker F (1990) Determination of duration of ovulation in gilts by means of laparoscopy Reproduction in Domestic Animals $25184-190$

Colenbrander B (1991) Commercial use of swine AI worldwide: a roundtable Reproduction in Domestic Animals Supplement 1 298-333

Day BN and Polge C (1968) Effects of progesterone on fertilization and egg transport in the pig Journal of Reproduction and Fertility 17 227-230

Demolt RP and Suarez SS (1992) Hyperactivated sperm progress in the mouse oviduct Biology of Reproduction 46 779-785

Didion BA and Schoenbeck RA (1996) Fertility of frozen boar semen used for AI in commercial settings Reproduction in Domestic Animals 31 175-178

Dziuk P (1970) Estimation of optimum time for insemination of gilts and ewes by double-mating at certain times relative to ovulation Journal of Reproduction and Fertility 22 277-282

Einarsson S (1985) Transport of boar sperm in the female reproductive tract. In Decp Freezing of Boar Semen pp 180-198
Eds LA Johnson and $K$ Larsson. Swedish University of Agricultural Sciences, Uppsala

First NL, Short RE, Peters JB, Stratmen FW (1968) Transport and loss of boar spermatozoa in the reproductive tract of the sow Journal of Animal Science 27 1037-1040

Flowers WL, and Esbenshade KL (1993) Optimizing management of natural and artificial matings in swine joumal of Reproduction and Fertility Supplement 48 217-228

Hancock JL. (1962) Fertilization in farm animals Animal Breeding Abstracts 30 285-310

Hancock JL and Hovell GJR (1962) Insemination before and after onset of heat in sows Animal Production 491-96

Helmond FA, Aamink A and Oudenaarden C (1986) Preovulatory hormone profiles in relation to embryonic development and mortality in pigs. In Embryonic Mortality in Farm Animals, pp 165-187 Ed. ESE Hafez. Lea and Febiger, Philadelphia

Hunter RHF (1967a) The effect of delayed insemination on fertilization and early cleavage in the pig Journal of Reproduction and Fertility 13 133-147

Hunter RHF (1967b) Polyspermic fertilization in pigs during the luteal phase of the oestrous cycle joumal of Experimental Zoology $165451-460$

Hunter RHF (1972) Ovulation in the pig: timing of the response to injection of hCC Research in Veterinary Science 13 356-361

Hunter RHF (1973) Polyspermic fertilization in pigs after tubal deposition of excessive numbers of spermatozoa joumal of Experimental Zoology 183 57-64

Hunter RHF (1974) Chronological and cytological details of fertilization and early embryonic development in the domestic pig, Stus scrofa. Anatomical Records 178 169-186

Hunter RHF (1982) Interrelationships betwcen spermatozoa, the female reproductive tract, and egg investments. In Control of Pig Reproduction, pp. 49-63. Eds DJA Cole and GR Foxcroft. Butterworths, London

Hunter RHF (1984) Pre-ovulatory arrest and peri-ovulatory redistribution of competent spermatozoa in the isthmus of the pig oviduct Joumal of Reproduction and Fertility 72 203-211

Hunter RHF (1990) Fertilization of pig eggs in vivo and in vitro. Journal of Reproduction and Fertility Supplement 40 211-226 
Hunter RHF (1994) Causes for failure of fertilization in domestic species. In Embryonic Mortality in Domestic Species pp 1-22 Eds MT Zavy and RD Geisert. CRC Press Inc., Boca Raton

Larsson K (1976) Fertility of deep frozen boar spermatozoa at various intervals between insemination and induced ovulation. Influences of boars and thawing diluents Acta Veterinaria Scandineroica 17 63-73

Larsson K, Swenson T and Wass K (1979) A field trial on the fertility of liquid boars semen after utilization of two different diluents Nordisk Veterinaermedicin 31 337-338

Lovell JE and Getty R (1968) Fate of semen in the uterus of the sow: histological study of endometrium during $27 \mathrm{~h}$ after natural service American Journal of Veterinary Research 29 $609-625$

Machaty Z, Takacs T and Gathy I (1992) Fertilizing capacity of boar semen diluted with B'TS and Modified Kiev (MK) extenders in relation to storage time and number of spermatozoa per insemination dose Animal Reproduction Science 29 289-295

Mburu JN, Einarsson S, Dalin AM, and Rodriquez-Martinez H (1995) Ovulation as determined by transrectal ultrasonography in multiparous sows: relationships with oestrus symptoms and hormonal profiles Journal of Veterinary Medicine Series A 42 285-292

Mburu JN, Einarsson S, Lundeheim N, and Rodriquez-Martinez H (1996) Distribution, number and membrane integrity of spermatozoa in the pig oviduct in relation to spontaneous ovulation Animal Reproduction Science 45 109-121

Nissen AK, Soede NM, Hyttel P, Schmidt M and D'Hoore L (1997) The influence of time of insemination relative to time of ovulation on farrowing frequency and littersize in sows, as investigated by ultrasonography Theriogenology 47 1571-1582

Pope WF, Wilde MH and Xie S (1988) Effect of electrocautery of nonovulated day 1 follicles on subsequent morphological variation amoung day 11 porcine embryos Biology of Reproduction 39 822-887

Pursel VG, Schulmann LL and Johnson LA (1978) Distribution and morphology of fresh and frozen-thawed sperm in the reproductive tract of gilts after artificial insemination Biology of Reproduction 19 69-76

Raychoudhury SS and Suarez SS (1991) Porcine sperm binding to oviductal explants in culture Theriogenology 36 1059-1070

Reed HCB (1985) Current use of frozen boar semen - future needs of frozen semen. In Deep Freezing of Boar Semen pp 225-238 Eds LA Johnsen and K Larrson. Swedish University of Agricultural Sciences, Uppsala

Rigby JP (1966) The persistence of spermatozoa at the utero-tubal junction of the sow Joumal of Reproduction and Fertility 11 153-155

Saacke RG (1982) Semen quality in relation to semen preservation Joumal of Dairy Science 66 2635-2644

Sather AP, Harbison DS and Seth PC (1991) A note on the influence of storage duration of fresh semen on fertilizing capacity and embryo survival in sows Animal Production 52 554-557

Smith TT and Yanagimachi R (1990) The viability of hamster spermatozoa stored in the isthmus of the oviduct: the importance of sperm-epithelium contact for survival Biology of Reproduction 42 450-457
Smith TT and Yanagimachi R (1991) Attachment and release of spermatozoa from the caudal isthmus of the hamster oviduct Journal of Reproduction and Fertility 91 $567-573$

Soede NM and Kemp B (1993) In synchronized pigs, the duration of ovulation is not affected by insemination and not a determinant for early embryonic diversity Theriogenology 39 1043-1053

Soede NM and Kemp B (1997) Expression of cestrus and timing of ovulation in pigs Journal of Reproduction and Fertility Supplement 52 91-103

Soede NM, Noordhuizen JPTM and Kemp B (1992) The duration of ovulation in pigs, studied by transrectal ultrasonography, is not related to early embryonic diversity Theriogenology 38 653-666

Soede NM, Helmond FA and Kemp B (1994) Periovulatory profiles of oestradiol, LH and progesterone in relation to oestrus and embryo mortality in multiparous sows using transrectal ultrasonography to detect ovulation fournal of Reproduction and Fertility 101 633-641

Soede NM, Wetzels CCH, Zondag W, de Koning MAl and Kemp B (1995a) Effects of time of insemination relative to ovulation, as determined by ultrasonography, on fertilization rate and accesssory sperm count in sows Joumal of Reproduction and Fertility 104 99-106

Soede NM, Wetzels CCH, Zondag W, Hazeleger W, and Kemp B (1995b) Effects of a second insemination after ovulation on fertilization rate and accessory sperm count in sows Journal of Repraduction and Fertility 105 135-140

Steverink DWB, Soede NM, Bouwman EG and Kemp B (1997) Influence of insemination-ovulation interval and spermcell dose on fertilization in sows joumal of Repraduction and Fertility 111 165-171

Suarez SS, Redfem K, Raynor P, Martin F, Phillips DM (1991) Attachment of boar sperm to mucosal explants of the oviduct: possible role in formation of a sperm reservoir Biology of Reproduction 44 998-1004

Viring $S$ and Einarsson S (1980) Influence of boar seminal plasma on the distribution of spermatozoa in the genital tract of gilts Acta Veterinaria Scandinavica 21 589-606

Viring $S$ and Einarsson $S$ (1981) Sperm distribution within the genital tract of natural inseminated gilts Nordisk Veterinar Medicin 33 145-149

Waberski, D, Dirksen G, Weitze KF, Leidig C and Hahn R (1990) Spermierumotilitat und morphology in ihrer auswirkung af die fruchtbarkeit von besamungsebem in feldversuchen Tierartztliche Praxis 18 591-594

Waberski D, Weitze KF, Gleumes T, Schwartz M, Willmen T and Petzholdt R (1994a) Effects of time of insemination relative to ovulation on fertility with liquid and frozen boar semen Theriogenology 42 831-840

Waberski $D$, Weitze KF, Lietmann $C$, Lubbert zur Lage $W$, Bortolozzo FP, Willmen T, Petzoldt R (1994b) The initial fertilizing capacity of longterm stored liquid semen following pre- and postovulatory insemination Theriogenology 41 1367-1377

Willemse AH and Boender J (1967) The relation between the time of insemination and fertility in gilts Tijdschrift Diergeneeskunde 92 18-34 